\title{
Non-Muslim Customer Preferences towards Islamic Banks in Semarang
}

\section{Preferensi Nasabah Non-Muslim terhadap Perbankan Syariah di Semarang}

\author{
Nur Baethi Hariyana1, Laily Dwi Arsyianti ${ }^{2}$ \\ Department of Islamic Economics, Faculty of Economics and Management, IPB University \\ Bogor, Indonesia 16680, email: ${ }^{1}$ nurbaethi21@gmail.com, ${ }^{2}$ arsyianti@apps.ipb.ac.id
}

\begin{abstract}
The prohibition of riba is applied by all religions. Islamic banking has a potential to attract non-Muslim customers. Semarang, both the regency and the city, has the largest non-Muslim population in Central Java. Currently, the number customers using Islamic banks has reached 22 million in 2017. This nominal can be escalated by elaborating non-Muslim preference towards Islamic banks. Therefore, this study aims to determine the factors that influence the preferences of non-Muslim customers towards Islamic banks in Semarang regency and the city. There are 120 respondents who have been interviewed, consisting of 60 respondents are Islamic bank customers and 60 respondents are conventional bank customers. They are selected based on non-probability sampling technique. Logistic regression method is employed to analyze the data. Results show the preferences of non-Muslim customers using Islamic banks are knowledge, profit sharing, religions, administrative profit, and income. Islamic banks can target non-Muslim customers through actively involved in disseminating Islamic financial products.
\end{abstract}

Keywords: Islamic banks, logistic regression analysis, non-Muslim customers

\begin{abstract}
Abstrak. Larangan riba adalah aturan yang terdapat pada semua agama. Hal ini memberikan potensi bagi perbankan syariah untuk menarik nasabah non-Muslim. Kabupaten dan Kota Semarang memiliki jumlah penduduk beragama non-Muslim terbesar di Jawa Tengah. Saat ini jumlah nasabah yang menggunakan bank syariah telah mencapai 22 juta pada tahun 2017. Angka ini masih berpotensi untuk ditingkatkan dengan mengidentifikasi preferensi nasabah non-Muslim dalam memilih bank syariah. Dengan demikian, penelitian ini bertujuan untuk mengetahui faktor yang memengaruhi preferensi nasabah non-Muslim terhadap bank syariah di Kabupaten dan Kota Semarang. Sebanyak 120 responden telah diteliti, dengan proporsi 60 responden nasabah bank syariah dan 60 responden lainnya adalah nasabah yang tidak menggunakan bank syariah. Sampel tersebut diambil dengan menggunakan teknik non-probability sampling dan metode analisis regresi logistik sebagai metode pengolahan data. Hasil penelitian menunjukkan bahwa faktor yang memengaruhi preferensi nasabah non-Muslim untuk menggunakan bank syariah adalah faktor pengetahuan, nisbah bagi hasil, religiusitas, keuntungan administrasi dan pendapatan. Dengan demikian bank syariah dapat menargetkan masyarakat non-Muslim dengan melakukan sosialisasi produk keuangan syariah untuk menjadi nasabahnya.
\end{abstract}

Kata kunci: Bank syariah, nasabah non-Muslim, regresi logistik

\section{INTRODUCTION}

Financial institutions are divided into bank and non-bank financial institutions. One of the bank financial institutions in Indonesia is commercial banks, both conventional commercial banks and sharia commercial banks. According to Law No. 10 of 1998 concerning Amendment to Law No. 7 of 1992 concerning Banking, Islamic banks were given a clear operational basis by the government thus marking the beginning of the era of a dual banking system in the Indonesian economic system.

The Indonesian economy had experienced a downturn due to the 1997-1998 monetary crisis. The crisis resulted in high inflation and interest rates, which affected all business sectors, including the banking sector, which resulted in several bank collapse. The monetary crisis resulted in conventional banking experiencing difficulties in carrying out the function of liquidity so that it needed to get recapitalization from the government (Barna, 2010). The impact of the monetary 
crisis on the first Islamic bank in Indonesia, namely Bank Muamalat Indonesia (BMI), which resulted in NPF (non-performing financing) of banks reaching 65.61\%. The amount of the elimination reserve fund to close the NPF is high, making a loss to the bank, thereby reducing two-thirds of the initial capital. However, the capital of BMI is still positive, so that BMI gets the predicate A by Bank Indonesia stated at Annual Report BMI 2008. This event concludes that during the monetary crisis, Islamic banking continued to show good performance compared to conventional banks such as Bank Bumi Daya (BBD), Bank Dagang Negara (BDN), Indonesian Development Bank (Bapindo), and Import Export Banks (Exim Bank) which eventually collapses. Following is the soundness of banks in 1998 viewed from ROA, CAR, and LDR (Table $1)$.

Table 1 Level of ROA, LDR, and CAR during the 1998 monetary crisis (\%)

\begin{tabular}{lrrr}
\hline & ROA & LDR & CAR \\
\hline Conventional Banks & & & \\
BBD & -127.18 & 130.96 & -39.57 \\
BDN & -106.59 & 174.74 & -79.30 \\
Bank Exim & -158.91 & 191.19 & -144.91 \\
Bapindo & -106.76 & 128.51 & -30.44 \\
Islamic Bank & & & \\
BMI & -23.94 & 107.15 & 6.76 \\
\hline
\end{tabular}

Source: Annual Report of BMI and Special Coverage of Banking, 2018 (edited)

The achievements of Islamic banks in overcoming these economic problems made Islamic banking began to be developed immediately after the monetary crisis has passed. Up to 2018 in Indonesia there are 14 Islamic commercial banks, 20 Islamic business units, and 168 Islamic rural banks. The growth of Islamic banking assets in Indonesia in 2018 was quite rapid at $18.05 \%$, compared to its conventional banks counterparty which was only $14 \%$. However, the growth of Third Party Funds (DPK) is still very far compared to conventional banking. The total deposits as of November 2017 collected by all commercial banks in Indonesia amounted to Rp519,948 trillion, this value grew 9.8\% compared to the previous period with the amount of Rp473,397 trillion (OJK, 2018). The percentage of $95 \%$ of deposits is dominated by conventional banks while $5 \%$ is controlled by Islamic banking. The market share of Islamic banking is still relatively small which has exactly 5.44\% of total banking share in 2017.

One way to improve the development of Islamic banking, especially the market share, is to convert or spin off from regional banks or conventional banks to Islamic banks (Antonio, 2016). Conversion is the transfer of a conventional bank or regional bank to an Islamic bank. One example is Bank Aceh which was successfully converted into an Islamic bank. Another method is spin off, which is the separation of ownership from a sharia business unit owned by a conventional commercial bank into an Islamic commercial bank, if the assets of the Islamic business unit have reached 50\% of the total assets of the parent. Commercial banks in Indonesia that have successfully carried out spin off are the BJB Syariah and BNI Syariah in 2010. BNI Syariah within 6 months after spinning off managed to get a net profit of 36.5 billion from the target of 7.181 billion (Anggraini et al., 2017). The achievement proved that spin off could potentially increase the market share of Islamic banking.

The development of Islamic banking in Indonesia cannot be separated from the factor of the population of Indonesia. The Republic of Indonesia Central Bureau of Statistics (BPS) published data that based on the 2010 population census, Indonesia has a total population of 237,641,326 people divided into 33 provinces. With this number, Indonesia is one of the fourth largest population in the world based on the CIA World Factbook annual report (Dina, 2016). The population of Indonesia is dominated by a population of Muslims with a total of 207,176,162 
people. This opens up a great opportunity for the Islamic finance industry to develop and compete with conventional financial institutions, especially banks.

In its development, the target of the Islamic banking market is not only Muslim communities, but the non-Muslim community can also be the target of marketing Islamic banking products. Islamic banking products are general, intended for all groups, including non-Muslim communities. In Indonesia, many non-Muslim communities have become customers of Islamic banks. The existence of Islamic bank customers from the non-Muslim community at Bank Permata Syariah has proved it, which is as much as approximately $38 \%$ or 170,000 people from the total existing customers are non-Muslim customers. The thing that makes non-Muslim customers interested in Bank Permata Syariah is because the equivalent profit sharing ratio of savings is 5\% (Rostanti \& Zuraya, 2013). Not only in Indonesia, in other countries with the majority of the non-Muslim community, Islamic banking can develop well, as it can increase self-confidence for Islamic banking has the potential to grow rapidly and attract the interest of the entire community.

Several countries in Europe have developed economic systems based on Islamic principles that apply the revenue sharing system according to Kartajaya and Sula (2016) in Nurhipnudin (2015). Even Singapore plans as a center for Islamic finance in Asia and even the world. This is proved by the consistency and reputation of Singapore in running an Islamic financial system (Rama, 2015). Until now, there are several Islamic financial institutions in Singapore, one of which is the Asian Islamic Bank which is the first Islamic Bank in Singapore. The Islamic Finance Country Index (IFCI) as the oldest institution that observes and evaluates ratings from various countries in connection with the state of Islamic banking and finance (IBF) in the world, finds that Islamic financial institutions do not only develop in Muslim countries or countries dominated by Muslim religious communities. The scoring system that is an indicator of IFCI ranking is the percentage variable of Islamic banking, IBFIs, Sharia Supervisory Regime (SSR), Islamic Financial Assets (IFA), Muslim Population (MP), Islamic Capital Market (ICM), Education and Culture (EC), and Islamic Regulation \& Law (IRL).

Table 2 IFCI ranking

\begin{tabular}{|c|c|c|c|c|c|c|c|c|c|}
\hline Country & Rank & В\% & $\begin{array}{c}\text { IBFIs } \\
\%\end{array}$ & $\begin{array}{c}\text { SSR } \\
\%\end{array}$ & $\begin{array}{c}\text { IFA } \\
\%\end{array}$ & $\begin{array}{c}\text { MP } \\
\%\end{array}$ & $\begin{array}{c}\text { ICM } \\
\%\end{array}$ & EC\% & IRL \% \\
\hline Sudan & 11 & 14 & 15 & 15 & 11 & 13 & 13 & 9 & 10 \\
\hline $\begin{array}{l}\text { United } \\
\text { Kingdom }\end{array}$ & 17 & 25 & 26 & 0 & 14 & 1 & 15 & 10 & 9 \\
\hline Srilanka & 18 & 31 & 33 & 1 & 14 & 2 & 1 & 14 & 4 \\
\hline USA & 19 & 26 & 28 & 0 & 20 & 1 & 15 & 9 & 1 \\
\hline Kenya & 21 & 25 & 30 & 2 & 19 & 12 & 4 & 5 & 3 \\
\hline Nigeria & 23 & 24 & 25 & 6 & 15 & 10 & 7 & 6 & 7 \\
\hline Singapore & 25 & 10 & 7 & 0 & 49 & 1 & 26 & 3 & 4 \\
\hline Switzerland & 26 & 23 & 28 & 0 & 21 & 0 & 18 & 6 & 4 \\
\hline South Africa & 28 & 26 & 27 & 3 & 18 & 4 & 8 & 7 & 7 \\
\hline Thailand & 30 & 31 & 33 & 3 & 10 & 7 & 3 & 7 & 6 \\
\hline Australia & 34 & 0 & 30 & 3 & 40 & 0 & 1 & 23 & 1 \\
\hline France & 38 & 0 & 0 & 0 & 54 & 0 & 23 & 23 & 0 \\
\hline Germany & 39 & 33 & 35 & 0 & 30 & 0 & 1 & 1 & 0 \\
\hline Philippines & 40 & 38 & 39 & 0 & 9 & 3 & 7 & 1 & 3 \\
\hline China & 41 & 0 & 80 & 0 & 5 & 15 & 0 & 0 & 0 \\
\hline
\end{tabular}

Source : Islamic Finance Country Index (IFCI) 2017 
Table 2 shows that the United Kingdom (UK) has a fairly good development of sharia economic systems even though the majority of the population is non-Muslim. UK develops a sharia economic system to overcome high social inequalities. In 2004, UK established Islamic Bank of Britain (IBB) which succeeded in getting 50,000 customers in the first year the bank was established (Aisyah, 2017). Sri Lanka with the majority of the Buddhist population has Islamic banking institutions that get the top ranking of the best Islamic Bank category by the Islamic Finance Forum of South Asia (IFFSA), Amana Bank. United State of America (USA) began to develop Standard Chartered Bank and J. P. Morgan by offering sharia banking products so that the development of Islamic banking was growing (Budiawati, 2017). This shows that there are many or at least the number of non-Muslim communities in a country that do not hinder the Islamic financial system from developing. Similarly, the preferences of customers or partners of Islamic financial institutions, not only Muslim communities, but non-Muslim communities are also interested in becoming customers of Islamic financial institutions.

Indonesia ranks seventh in the IFCI 2017 rankings and gets a classification as a moderate country in the field of Islamic Banking and Financial IFCI 2017. According to the Indonesian Population Census data in 2010 the population of non-Muslims reached 30,465,164 people or $12.81 \%$ of the total population of Indonesia. Five religions recognized in Indonesia according to legislation are spread into 33 provinces. One of the provinces with the highest population in Indonesia is in Central Java Province which is ranked third in the most populous provinces in Indonesia after the provinces of West Java and East Java, with a population of 32,382,657 in 2010. Central Java Province is also the province with the 10th largest non-Muslim population in Indonesia, there are 969,545 non-Muslim inhabitants which constitute 3\% of the total population in Central Java Province. Based on these data it can be assumed that Central Java has the potential in developing Islamic banking with the target of non-Muslims.

Table 3 Data on non-Muslim population in Central Java Province

\begin{tabular}{lr}
\hline Religion & Number of Non-Muslim Populations \\
\hline Christian & 572,517 \\
Chatolic & 317,919 \\
Buddhist & 53,009 \\
Hindu & 17,448 \\
Khong Hu Chu & 2,995 \\
Others & 5,657 \\
\hline Total & $\mathbf{9 6 9 , 5 4 5}$ \\
\hline
\end{tabular}

Source: BPS (2010) Indonesia

Districts and cities with the densest population in Central Java are districts and the city of Semarang which reached $2,486,711$ people with a percentage of $7.7 \%$ of the total population in Central Java. The number of non-Muslim residents in the city and regency of Semarang is 257,559 people, which is $10.36 \%$ of the total population of the city and regency of Semarang. Islamic banks are currently expanding massively. The number of customers that have reached 22 million in 2017 shows a 10\% growth from the previous year (Lilis, 2017). Asset growth also increased from January to August 2017, reaching 6.57\%.

Meanwhile, Islamic finance increased by $7.92 \%$, and Third Party Funds (TPF) reached $10.59 \%$. Overall, Islamic economic growth reached $23.17 \%$, increased funding reached $21.10 \%$, and deposits reached $25.99 \%$. Indonesia is a potential market in the development of one of the Islamic economic systems through the Islamic banking industry. This happens when supported by all Indonesian people who are predominantly Muslim.

However, behind this expansion, the paradigm is still conceptualized that Islamic economic systems, including Islamic banking, are only intended for Muslim communities. The paradigm of 
religious fanaticism is still very conceptualized in today's society's mindset, so that public perceptions of the sharia market are still understood as the Muslim market (Rifai, 2017). Even though in reality the economic system based on sharia principles is general or intended for many people not only the Muslim community. Although the community's mindset of Islamic banking is specifically intended for the Muslim community, not a few non-Muslim communities have become customers of Islamic banks, for example the Bank Permata Semarang Islamic Branch Office which has 15 non-Muslim customers in 2018. The market shares of Central Java Islamic banking in 2017 reached $4.38 \%$ and total assets experienced an $8.48 \%$ increase in 2017 to $10.73 \%$ in 2018. This shows that Islamic banking has the potential to develop in Central Java with a target market of Muslim and non-Muslim communities.

As sustainable development goals (SDGs) also aim to strengthen the existence of institutions to create sustainable communities by providing decent work and economic growth, Islamic banks should have prepared those sharia-compliant development goals to achieve the ultimate goal, i.e. the hereafter. For its further sustainability, Islamic banks should target wider customers since Islam is rahmatan lil alamin (for all human beings). In order to gradually achieve the goals, this paper try to help Islamic banks to analyse the non-Muslim preference towards Islamic banks, i.e. what factors affecting them to choose Islamic bank as their partner in financial life.

\section{LITERATURE REVIEW}

\section{Preference}

Preferences are preferences or choices that consumers prefer to consume in an item. Preference is formed from the mindset or perspective of a consumer in choosing a product (Munandar et al., 2012). Preference is the right to prioritize and take precedence over others. Preference is also a priority, choice, preference, or tendency. The field of social science, especially economics, generally uses the concept of preference which assumes the reality between alternatives with the possibility of choosing other alternatives based on meeting the needs, product uses, satisfaction and pleasure in choosing a product.

Consumer preference theory presents three basic traits which are the assumptions of consumer preference relations, namely completeness, transitivity, and continuity. Completeness explains that consumers must be able to choose one of the various alternative choices. The nature of transitivity is the condition of consumers who cannot explain their preferences which are contrary to the tendency to choose a particular product compared to other products. Then the assumption of the last nature is continuity, which is a condition where the consumer accepts all conditions for the chosen choice. The choice of a product, that is more in demand by consumers, expresses more satisfaction than other items. In addition to being influenced by the form or type of goods and or services, customer satisfaction can also be measured based on personal experience, psychological attitudes, and group and environmental influences according to Nicholson (2002) in Puspasari et al. (2017).

In economics, preference cannot be separated from the theory of demand or demand. Demand is the amount of goods demanded by the market. This is assumed because every human being must have needs. To meet these needs, the demand for goods or services arises as a means of fulfilling needs. Purpose of preference as the final decision of consumers in consuming a product with the aim of achieving customer satisfaction. With the preference as a consumer priority and supported by available budget funds, showing the number of items that can be purchased by consumers. Conventionally, consumers can maximize desired satisfaction with a limited budget, if consumers can make choices rationally (Sugiarto et al., 2000). 


\section{Riba According to The Islamic Religion and Non-Islam Religion Point of View}

Riba according to Arabic means additional or excess of the principal amount borrowed, though additional supplements are small. Riba according to the term is an addition to the principal property in the accounts receivable or trade debt transactions. The additions are false because there is an element of injustice that results in tyranny for either party is creditors and borrowers or buyers. Thus the essence of riba is the injustice for those who need the property, and should get help from the parties who have more property, but have to pay extra on the borrowed capital so that there is an element of tyranny in riba (usury).

Islam forbids usury that is recorded in the Quran and passed through four stages (Ayyubi \& Lubis, 2015). The first level is revealed in the Surah Ar-Rum verse 39 which contains the meaning "And something usury or extra that you give him to increase in human property, then it does not add to God's view. And what ye give in the form of charity, which ye mean for the pleasure of Allah".

The second stage is revealed in the Surah An-Nisa verse 160-161 which means "It was because of the Jews' cruelty, We forbade them to eat good food for the sake of them, and because they often hinder (men) from the way of Allah. And because they devoured usury, yet they were forbidden from it, and because they devoured the wealth of the people in vanity. We have prepared for the disbelievers among them a painful torment."

The third stage of the riba verse is that in the Surah Ali Imran verse 130 which means "O you who believe, do not devour usury by multiplying and fear Allah that ye may prosper." Then the last stage of the riba verse is revealed in the Surah Al-Baqarah verse 278-279 which means "O ye who believe! Fear Allah and leave the rest of usury if you are believers. So if you do not (leave the rest of usury), then know that Allah and His Messenger will fight you. And if you repent (from usury), your property is yours, you will not be wronged nor will you be wronged."

Historically for non-Islam religions, the prohibition of usury has actually been discussed since 2000 BC, especially for divine religions, such as Buddhism, Hinduism, Judaism, and Christianity. The oldest literature describing usury is found in ancient Indian Vedic texts (2000-1400 BC) as written by Jain (1929) in Indigenous Banking in India where usury (cusidin) is referred to repeatedly and interpreted as lending with interest. It is found in the text of the Sutra (7000-100 BC) and Jataka in Buddhism (600-400 BC) where the prohibition of usury or interest is for the Brahman and Kshatriya castes.

According to Antonio (2001) in Ayyubi and Lubis (2015) the concept of usury in Judaism is known as neshekh, the prohibition of usury has been discussed in the Jewish religious scriptures as well, both in the Old Testament and in the Talmudic law. Quoted from Old Testament in the book Levicitus (Leviticus) article 25 verses 36-37 which reads "You must not take interest from money or usury, but you must fear your God, so that your brother can live among you. Thou shalt not give your money to him by asking for flowers, nor do you give your food by asking usury".

According to the Christian religious perspective quoted from the Christian holy book Ezekiel chapter 18 verse 8 which reads, "Whoever does not collect money or takes usury, abstains from dishonesty, then he has conducted a benevolent assessment between man and man". In the verse explains that riba according to Christians is also prohibited because it can hurt others especially the poor. In Deuteronomy chapter 23 verse 19-20 it is related to the prohibition of collecting interest from a native of the nation, "Do not lend to your brother, money or food or anything that can be multiplied". "From strangers you may collect flowers, but from thy brother thou shalt not glean a flower - that the LORD thy God may bless thee in all the affairs of the land whither thou goest to possess it.". Therefore, basically, all religions prohibit riba to be applied in economic activities. 


\section{Islamic Banking}

Islamic financial and banking institutions are institutions or business entities in the field of finance whose duty is to issue and collect funds from the community, especially in providing credit and services in payment transactions and money in circulation. Islamic banking is a banking system that is carried out based on the basic principles of Islamic law or sharia. The prohibition to collect loans or lend with the addition of loan interest in Islam is illegal. Investing in businesses that are categorized as illegitimate in Islam is also prohibited, so the Islamic banking system is formed.

Islamic banks are banks operated on the basis of Islamic law. Islamic banks began to develop since the emergence of Bank Muamalat in 1992, then followed by the emergence of other Islamic banks. By implementing a ban on usury activities, speculation, obscurity and injustice in transactions are able to meet the needs of the community for financial institutions whose management is in accordance with sharia principles. Since then, the existence of Islamic banks has slowly begun to align with conventional banks.

\section{Products of Islamic Banks}

\section{Wadiah savings}

The principle of the wadiah product is the deposit of the fund from the party who has the funds to the other party as the fund manager, with the record that the fund should not be utilized and can be taken at any time upon requests.

\section{Mudharabah savings}

The principle of a savings product with mudharabah contract is investment, where the customer gets a profit sharing ratio for the funds invested in accordance with the agreement, and if there is a loss, it will be borne by the party who is entrusted with the funds.

\section{Mudharabah deposits}

Mudharabah principle is the cooperation between the owner of the capital (shahibul maal) and the capital manager (mudharib) with the profit sharing ratio in accordance with the agreement agreement or agreement before the execution of cooperation. For losses suffered by capital owners (shahibul maal), except for negligence of the manager.

\section{Previous Studies}

There are some previous studies that discuss customer preferences for Islamic banks, among others, research conducted by Machmudah (2009) with the title Factors Affecting the Interest of Non-Muslim Customers to Become Customers in Islamic Banks (Study of Bank CIMB Niaga Syariah Branch Semarang) using the method processing data using descriptive analysis and multiple regression. The results of the study shows the location, service, religious stimuli, reputation, profit sharing, and promotion of the interest of non-Muslim customers to become Islamic bank customers so that customers are interested in choosing to use Islamic banks.

Hapsari and Beik (2014) analysed Factors Affecting Non-Muslim Customers in Using Sharia Bank Services in DKI Jakarta, with data collection methods using purposive sampling, logistic regression and descriptive analysis as a method of data processing. The results of the study variables that positively influence the decisions of non-Muslim customers in choosing Islamic banks are location, religion, and administrative benefits.

Nurhipnudin (2015) studied the Analysis of Factors Affecting Interest in Transaction of NonMuslim Students in Islamic Banks, with purposive sampling technique, multiple regression data processing methods. The results of these studies are factors that positively influence the decisions of non-Muslim students in transactions using Islamic banks are product variables and promotions. This shows that the level of promotion and products of Islamic banks will be an opportunity to increase non-Muslim students to transact using Islamic banks. 
Haris (2015) researched Analysis of Factors Affecting Customer Preferences on Sharia Banks in DKI Jakarta, with purposive sampling techniques, descriptive data processing methods and logistic regression. The results of these studies are factors that have a positive effect on respondents' decisions in choosing to use Islamic banks are education variables, knowledge, expenditure, and facilities. This shows that the higher the level of education and knowledge about the Islamic banking system, economic stability (expenditure), and the completeness of facilities, will be an opportunity to increase the community in using services from Islamic banks.

Yatie (2014) conducted research with the title of Analysis of Factors Affecting Customers Saving a Case Study of Islamic Banks in Surabaya. The research uses descriptive analysis method showing the results of the level of service and products provided by Islamic banks to customers is a factor that influences customers to save at Islamic banks.

\section{METHOD}

\section{Sampling Method}

The sampling method in this study uses a non-probability sampling method, that is a type of sampling that is done not randomly, so that not all populations have the opportunity to be sampled. Only a portion of the population chosen as a sample is due to coincidence or something planned by the researcher. This technique is used because researchers do not know the population in detail. This sampling method uses a purposive technique and snowball sampling. The number of samples is always included in the statistical test measurements. Statistical tests using the number of samples from 30 to 60 or 120 to 250 will get efficient results, but it is not recommended if the number of samples above 500 uses statistical tests according to Champion (1981) in Mustafa (2000). The sampling technique in this study by distributing questionnaires and interviews to 120 non-Muslim customers, with details of 60 non-Muslim customers who use Islamic banks and 60 non-Muslim customers who do not use Islamic banks.

\section{Data Analysis}

In the study of preferences of non-Muslim customers in choosing Islamic banks, descriptive data analysis methods and logistic regression were used as data analysis methods. This study uses secondary and primary data collection methods. Before primary data collection through interviews, the questionnaire has fulfilled the assumption of validity test and reliability test. This study uses Microsoft Excel 2010 application software for data recapitulation and SPSS 24 for data processing.

Logistic regression model is a method used to explain the factors that affect non-Muslim customers using Islamic banks. The logistic regression model is an equation that results from a linear regression model where the dependent variable is categorical. The basic category of logit models is the numbers 0 and 1 . Number 1 interprets non-Muslim customers who use Islamic banks and the number 0 interprets non-Muslim customers who do not use Islamic banks. The following logistic regression model will be used:

$$
\pi=\frac{e^{\alpha}+\beta_{1} x_{1}+\beta_{2} x_{2}+\beta_{3} x_{3}+\beta_{4} x_{4}+\beta_{5} x_{5}+\beta_{6} x_{6}+\beta_{7} x_{7}}{1+e^{\alpha}+\beta_{1} x_{1}+\beta_{2} x_{2}+\beta_{3} x_{3}+\beta_{4} x_{4}+\beta_{5} x_{5}+\beta_{6} x_{6}+\beta_{7} x_{7}}+e
$$

\section{Where :}

$\pi \quad:$ Preference for non-Muslim customers to choose Islamic banks

$\alpha \quad$ : Intercept

$\beta_{\mathrm{i}} \quad$ : Variable parameters

$x_{1} \quad:$ Knowledge level (score)

$x_{2} \quad:$ Accessibility (score)

$x_{3} \quad$ : Profit sharing rate (score) 


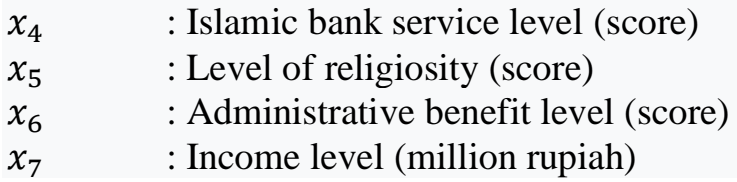

In a regression analysis the easy-to-use logistic interpretation model uses odds ratios. In the odds ratio can be interpreted as "how many times is the possibility of choice 1 among individuals with $X=1$ compared to among individuals with $X=0$ " (Juanda, 2009). Odds ratios are used to see opportunities for choice 1 where non-Muslim customers use Islamic banks for opportunities for 0 choices where non-Muslim customers do not use Islamic banks. The greater the odds ratio is directly proportional to the probability of the tendency of non-Muslim customers to use Islamic banks. The following is the relationship between odds ratios and parameters:

$$
\text { Odds ratio }=\frac{\pi_{i}}{1-\pi_{i}}
$$

Where :

$\pi_{i} \quad$ : Choice odds ratio 1

\section{Variables and Definitions}

The variables used in this study and their operational definitions are:

1 The level of customer knowledge about Islamic law affects the choice of Islamic banks. The level of knowledge has a positive effect on customer preferences choosing Islamic bank products (Haris, 2015). This study measures the level of one's knowledge of Islamic banks and contracts used in using Islamic banks.

2 The tendency of customers to use Islamic banks is supported by bank location accessibility facilities with work locations or customers' residences. The result has a positive influence on the preferences of non-Muslim customers to choose the services of Islamic banks (Hapsari \& Beik, 2014).

3 Profit sharing ratio is a term used in Islamic banks, and the concept is different from the rate or interest used in conventional banks. Profit sharing ratio has a positive effect on the preferences of non-Muslim customers to become customers of Islamic banks (Machmudah, 2009). This study measures the amount of profit sharing ratio that shows the benefits obtained by customers, and determines the preferences of customers in choosing Islamic banks.

4 High customer mobility expects performance or all community needs to be fulfilled optimally with effective time. The higher the level of service and facilities of the bank, the higher the level of efficiency and effectiveness of the bank (Haris, 2015). Service performance, facilities, and variations of Islamic bank products determine customer preferences in using Islamic banks.

5 The level of religiosity is a factor that influences individuals to carry out economic actions (Machmudah, 2009). Indicators to measure the level of religiosity of respondents in this study by knowing the intensity of worship of respondents, the level of understanding of usury, and the view of usury according to the religion adopted.

6 Administrative benefits in Islamic banks according to the Financial Services Authority Regulation (POJK) Article 5 paragraph 2 of 2014 are free account opening, monthly administration, incoming transfer transactions, cash deposit transactions, book-entry transactions, and account closures. This study uses indicators of whether Islamic banks are used free of administrative costs.

7 The income level of a customer will influence a person's preference in choosing a product that will be used with consideration of other product alternatives and limited income (Haris, 2015). Revenues earned by customers to meet their daily economic needs so that they can save. 


\section{RESULTS AND DISCUSSION}

Islamic banks in Indonesia currently have a market share with a value of 5.92\% in 2018, so that Islamic banks that expand throughout the Indonesian region make the target market of Islamic banks not only Muslim communities but non-Muslim communities also become the market leaders of Islamic banks. In this study, the independent variables as factors that influence the preferences of non-Muslim customers in Islamic banks include the level of knowledge, accessibility, profit sharing, provided services, level of religiosity, administrative benefits, and income. The dependent variable used uses a variable dummy, which is non-Muslim customers who do not use Islamic banks ( $\mathrm{Y}=0)$ and non-Muslim customers who use Islamic banks ( $\mathrm{Y}=1)$. This model uses a type I error of 5\% with a confidence level of $95 \%$ and $10 \%$ with a confidence level of $90 \%$. Table 4 shows the value of the Nagelkerke R Square test result is 0.855 . The results of this test depict that the factors affecting non-Muslim customers in choosing Islamic banks can be explained by $85.5 \%$ by the model.

Table 4 R square

Step $\quad-2$ Log likelihood $\quad$ Cox \& Snell R Square $\quad$ Nagelkerke R Square

\begin{tabular}{llll}
1 & $43.429^{\mathrm{a}}$ & .641 & .855 \\
\hline
\end{tabular}

a. Estimation terminated at iteration number 8 because parameter estimates changed by less than .001 .

Table 5 explains the results of Hosmer and Lemeshow test which is the significance value is 0.544 , where the value is greater than 0.05 and the Chi-square value is 6.929. If $\mathrm{p}$-value is more than the type I error, then accept $\mathrm{H}_{0}$, with a value of $0.544>0.05$ so accept $\mathrm{H}_{0}$. The chi-square value is greater than the type I error with the value of $6.929>0.05$ so accept $\mathrm{H}_{0}$. It can be concluded that the model has sufficiently explained the data or goodness of fit.

$\mathrm{H}_{0} \quad$ : the model has sufficiently explained the data (goodness of fit)

$\mathrm{H}_{1} \quad$ : the model has not sufficiently explained the data

Table 5 Hosmer and Lemeshow

\begin{tabular}{llcl}
\hline Step & Chi-square & df & Sig. \\
\hline 1 & 6.929 & 8 & .544 \\
\hline
\end{tabular}

Table 6 explains the prediction of the model's accuracy towards non-Muslim customers who do not use Islamic banks is $91.7 \%$ and non-Muslim customers who use Islamic banks are $93.3 \%$ where the total percentage prediction of model accuracy is $92.5 \%$.

Table 6 The accuracy of model predictions

\begin{tabular}{lllcl}
\hline & & \multicolumn{2}{c}{ Predicted } & \\
\cline { 3 - 4 } & & \multicolumn{2}{c}{ Respondents } & Percentage \\
\cline { 3 - 4 } Observed & $\begin{array}{l}\text { Non-Islamic } \\
\text { Bank Non- } \\
\text { Muslim } \\
\text { Customers }\end{array}$ & $\begin{array}{c}\text { Islamic Bank } \\
\text { Non-Muslim } \\
\text { Customers }\end{array}$ & \\
\hline Respondent & $\begin{array}{l}\text { Non-Islamic } \\
\text { Non-Muslim } \\
\text { Customers }\end{array}$ & 55 & 5 & 91.7 \\
\cline { 2 - 4 } & $\begin{array}{l}\text { Islamic Bank Non- } \\
\text { Muslim Customers }\end{array}$ & 4 & 56 & 93.3 \\
\hline & Overall Percentage & & & 92.5 \\
\hline
\end{tabular}

a. The cut value is .500 
Interpretation of significance results using odds ratios. Table 7 shows the results of logistic regression tests that significant variables in the factors affecting non-Muslim customers to deal with Islamic banks are knowledge, profit sharing, religiosity, administration benefits, and income. The knowledge variable is significant at the 0.05 level, significant profit sharing ratio at the level of 0.003 , the religiosity variable is significant at the 0.057 level, the administration benefits variable is significant at the level of 0.058 , and the income variable is significant at the 0.000 real level. The variables that are not significant are the accessibility and service levels with a real level of 0.899 and 0.879 .

Table 7 Factors influencing non-Muslim customers towards Islamic banks

\begin{tabular}{llrrr}
\hline & \multicolumn{2}{c}{ B } & \multicolumn{1}{c}{ Sig. } & \multicolumn{1}{c}{$\operatorname{Exp}(\mathrm{B})$} \\
\hline Step $1^{\mathrm{a}}$ & Knowledge & 1.009 & $.005^{*}$ & 2.743 \\
& Accessibility & .021 & .899 & 1.021 \\
& Profit sharing & 1.283 & $.003^{*}$ & 3.607 \\
Facility & -.033 & .879 & .968 \\
Religiosity & -.418 & $.057^{* *}$ & .658 \\
Benefits & .786 & $.058^{* *}$ & 2.195 \\
Income & .000 & $.000^{*}$ & 1.000 \\
Constant & -14.138 & .001 & .000 \\
\hline
\end{tabular}

* significant at $5 \%$ error

** significant at $10 \%$ error

Variables of knowledge, accessibility, profit sharing ratio, administrative benefits, and income are positive, indicating that the independent variable has a positive effect on non-Muslim customers in using Islamic banks. Meanwhile, services and religiosity variables have a negative effect on non-Muslim customers in using Islamic banks.

\section{Knowledge}

The knowledge level variable at the 5\% real level has a significant effect with an odds ratio of 2.743. It can be interpreted that the knowledgeable non-Muslim customers regarding Islamic banks have 2.743 times greater possibility for choosing Islamic banks than those non-Muslim customers who have lower level of knowledge. The variable of knowledge about Islamic banks, apparently, has a positive effect. The results of this study are in accordance with the theory of consumer behaviour where knowledge factors influence all information obtained by consumers in choosing goods and services (Sumarwan, 2011). This indicates that non-Muslim customers already know about the differences in Islamic banks with conventional banks. Consumer knowledge of Islamic banks is divided into product knowledge, purchases, and usage. Consumer knowledge regarding products from Islamic banks is higher than knowledge of the use and purchase of Islamic bank products (Megawaty, 2015). This can be interpreted that customers know the products in Islamic banks.

\section{Profit Sharing Rate}

The variable profit sharing ratio has a positive effect on the preferences of non-Muslim customers in choosing Islamic banks. The profit sharing rate at the 5\% real level has a significant effect on the odds ratio 1.021. These variables can be interpreted that the higher the level of profit sharing of Islamic banks, the higher the chance of non-Muslim customers in choosing Islamic banks, which is worth 1,021 times higher. Variable level of profit sharing can be said to be more profitable than the interest system, so that it affects the decisions of non-Muslim customers in choosing Islamic banks (Megawaty, 2015). The decision of non-Muslim customers in choosing Islamic banks is due to economic factors. 


\section{Religiosity}

The variable level of religiosity of non-Muslim customers has a negative coefficient. The level of religiosity of non-Muslim customers at the real level of $10 \%$ has a significant effect with an odds ratio of 0.658 . It can be interpreted that the lower the level of religiosity, the opportunity for nonMuslim customers is 0.658 times greater in choosing Islamic banks than those with higher level of religiosity. The level of religiosity of non-Muslim customers against the prohibition of usury varies so that it affects the decisions of non-Muslim customers in choosing Islamic banks.

The lower the level of religiosity of non-Muslim customers, the higher the chance of non-Muslim customers to choose Islamic banks. This is due to the paradigm of the non-Muslim community fanaticism which considers that Islamic banks are only intended for Muslim communities (Rifai, 2017). So that the more fanatical of the non-Muslim community towards their religion, the nonMuslim community will increasingly view that Islamic banks are only for Muslim communities.

\section{Administrative Benefits}

Profit level variables have positive coefficients. The profit level of non-Muslim customers at the $10 \%$ real level has a significant effect with an odds ratio of 2.195. It can be interpreted that the higher the benefits given by Islamic banks, the opportunity for non-Muslim customers is 2,195 times greater for choosing Islamic banks than the lower level of benefits. The reason for nonMuslim customers in choosing Islamic banks is because of economic factors. The existence of free administration fees affects the decisions of non-Muslim customers in choosing Islamic banks.

\section{Income}

The respondent's lowest income level is a half million rupiah and the highest income is 12.5 million rupiahs. The income level variable has positive coefficient. The profit rate of non-Muslim customers at the 5\% real level has a significant effect with a value of 1odds ratios. It can be interpreted that the opportunity for non-Muslim customers is 1 times greater for choosing Islamic banks when their income is higher. The income variable has a significant effect on the interest of customers to use Islamic banking services (Uniyanti, 2018).

\section{CONCLUSION AND RECOMMENDATIONS}

\section{Conclusion}

Based on the results of the analysis in the research conducted it can be concluded that the characteristics of non-Muslim customers who use Islamic banks are dominated by men, aged 3040 years, who are Christians. The last majority of education for non-Muslim Islamic bank customers is Strata-1 university level and works as a private employee. The majority of nonMuslim customers have been saving in Islamic banks in the last 1-2 years. Non-Muslim customers get information about Islamic banks through electronic media advertisements. The majority of non-Muslim customers use mudharabah savings products and the reason non-Muslim customers use Islamic banks is because the administrative costs of Islamic banks are low.

Based on logistic regression analysis, the independent variables that influence non-Muslim customers in using Islamic banks are knowledge factors, profit sharing, administrative benefits, and income, where all of these variables have a positive and significant effect on the decisions of non-Muslim customers using Islamic banks. While the religiosity factor has a negative and significant effect on the decisions of non-Muslim customers using Islamic banks.

\section{Recommendations}

Based on the research that has been done to examine the preferences of non-Muslim customers towards Islamic banks has influencing factors, namely the level of knowledge, profit sharing ratio, level of religiosity, profit level, and income level, the authors propose a number of suggestions, 
including young people can be potential targets to be withdrawn as sharia bank customers, thus Islamic banks need to increase socialization regarding Islamic banking to young people.

The tendency of respondents to get information about Islamic banks through electronic media advertisements. In increasing the level of promotion, Islamic banks can re-intensify promotional advertisements using electronic media through social media networks because the majority of today's millennials tend to get more information through social media.

The results of this study indicate that non-Muslim customers are fonder of mudharabah deposit products, thus, Islamic banks need to maintain product service quality. The next challenge is to increase promotion of other innovative yet sharia-compliant products for the products used by customers become more diverse.

Increasing public knowledge, especially non-Muslims related to Islamic banking products, and the advantages of Islamic banking. Islamic banks need to maintain a low administrative cost strategy because this still attracts non-Muslims to become customers of Islamic banks.

High income customers is affected by a high profit sharing ratio that makes customers interested in using Islamic banks as a form of investment. Islamic banks are predicted to increase investment products so that more people interested to invest in Islamic banks.

\section{REFERENCES}

Aisyah. (2017). Perkembangan Perbankan Syariah di Inggris [retrieved 2019 Mei 19]. Available at: http://www.ibec-febui.com/perkembangan-perbankan-syariah-di-inggris/.

Anggraini, R., Yuliani, \& Umrie, R. 2017. Analisis tingkat kesehatan bank syariah sebelum dan sesudah spin off. Ekspektra: Jurnal Bisnis dan Manajemen, 1(1), 11-20.

Antonio, S. 2016. Konversi Jadi Cara Tingkatkan Share Perbankan Syariah [retrieved 2019 Mei 19]. Available at: https://www.republika.co.id/berita/ekonomi/syariahekonomi/16/12/28/oiv8ye368-konversi-jadi-cara-tingkatkan-share-perbankan-syariah.

Ayyubi, S. E. \& Lubis. D. (2015). Filosofi Ekonomi Syariah. Bogor (ID), IPB Press.

Barna, F. P. (2010). Analisis Faktor-faktor yang Memengaruhi Preferensi Nasabah Bank Syariah. (Undergraduate Thesis, UIN Syariah Hidayatullah, Jakarta, Indonesia). Available at: http://repository.uinjkt.ac.id/dspace/handle/123456789/21527.

Budiawati, A. D. (2017). Industri Syariah AS Semakin Berkembang [retrieved 2019 Mei 19]. Available at: https://www.dream.co.id/dinar/industri-syariah-di-amerika-serikat-semakinberkembang-170320v.html.

Dina, M. (2016). Ledakan Jumlah Penduduk Sebabkan Peningkatan Beban Negara [retrieved 2019 Mei 1]. Available at: https://www.beritasatu.com/kesehatan/380628/ledakan-jumlahpenduduk-sebabkan-peningkatan-beban-negara.

Haris, M. (2015). Analisis Faktor-Faktor yang Mempengaruhi Preferensi Nasabah Terhadap Bank Syariah di DKI Jakarta. (Undergraduate Thesis, Institut Pertanian Bogor, Bogor, Indonesia). Available at: https://repository.ipb.ac.id/jspui/bitstream/123456789 /75934/1/H15mha.pdf.

Hapsari, F. T. \& Beik, I. S. (2014). Analisis faktor-faktor yang memengaruhi nasabah nonMuslim dalam menggunakan jasa bank syariah di DKI Jakarta. AL-MUZARA' AH, 2(1), 7594.

Lilis, S. (2017). Ternyata Ada 22 Juta Nasabah Bank Syariah [retrieved 2018 Juni 26]. Available at: http://wartakota.tribunnews.com/2017/10/07/ternyata-ada-22-juta-nasabah-banksyariah.

Jain, L. C. (1929). Indigenous banking in India. London (UK), Macmillan and Co, Limited.

Juanda, B. (2009). Ekonometrika Pemodelan dan Pendugaan. Bogor (ID), IPB Press.

Machmudah, R. (2009). Faktor-faktor Yang Memengaruhi Minat Nasabah Non Muslim Menjadi Nasabah Bank Syariah (Studi Pada Bank CIMB Niaga Syariah Cabang Semarang) 
(Undergraduate Thesis, IAIN Walisongo Semarang, Semarang, Indonesia). Available at: http://eprints.walisongo.ac.id/3760/.

Megawaty. (2015). Analisis Pengetahuan Konsumen Mengenai Perbankan Syariah dan Pengaruhnya terhadap Keputusan Menjadi Nasabah pada PT. Bank Tabungan Negara Syariah (Persero) Cabang Makassar. Makasar (ID), STIM Nitro Makassar.

Munandar, J. M., Udin, F., \& Amelia, M. (2012). Analisis faktor yang mempengaruhi preferensi konsumen produk air minum dalam kemasan di Bogor. Jurnal Teknologi Industri Pertanian, 13(3).

Mustafa, H. (2000). Teknik Sampling [retrieved 2019 Januari 28]. Available at: http://www.academia.edu.

Nurhipnudin, I. (2015). Analisis Faktor-faktor yang Memengaruhi Minat Bertransaksi Mahasiswa Non-Muslim pada Bank Syariah. (Undergraduate Thesis, IAIN Sunan Kalijaya, Yogyakarta, Indonesia).

Puspasari, E. D., Sarma, M., \& Najib, M. (2017). Preferensi konsumen dan strategi pemasaran produk puree bayam organik (Studi kasus: CV. Addin Abadi Bogor). Journal of Agroindustrial Technology, 27(2), 209-216.

Rama, A. (2015). Analisis deskriptif perkembangan perbankan syariah di Asia Tenggara. The Journal of Tauhidinomics, 1(2), 105-123.

Rostanti, Q. \& Zuraya, N. (2013). Nasabah Non-Muslim Permata Bank Syariah Capai 170 Ribu Orang [retrieved 2018 Juni 26]. Available at: https://www.republika.co.id/berita/ekonomi/syariahekonomi/13/05/03/mm7nur-nasabahnonmuslim-permatabank-syariah-capai-170-ribu-orang.

Rifai, N. (2017). Persepsi Masyarakat Non-Muslim terhadap Minat Menjadi Nasabah Bank Syariah di Surakarta. (Undergraduate Thesis, IAIN Surakarta, Indonesia).

Sugiarto, Kelana, S., Herlambang, T., Sudjana, R., \& Brastoro. (2000). Ekonomi Mikro Suatu Pendekatan Praktis. Jakarta (ID), PT Gramedia Pustaka Utama.

Sumarwan, U. (2011). Perilaku Konsumen: Teori dan Penerapannya dalam Pemasaran. Bogor (ID), Ghalia Indonesia.

Uniyanti. (2018). Faktor-faktor yang Memengaruhi Minat Nasabah Menabung di Bank Syariah. (Undergraduate Thesis, UIN Alauddin Makassar, Makassar, Indonesia). Available at: http://repositori.uin-alauddin.ac.id/12592/1/FAKTOR-FAKTOR\%20YANG\%20 MEMENGARUHI\%20MINAT\%20NASABAH.pdf.

Yatie, V. A. (2014). Analisis faktor-faktor yang mempengaruhi nasabah menabung: Studi kasus bank syariah di Surabaya. Jurnal Akuntansi UNESA, 3(1). 